\title{
CONSUMER PROTECTION AND CONSUMER EDUCATION: THE ROLE OF THE MEDIA IN THE NIGERIAN PHARMACEUTICAL INDUSTRY
}

\section{Chikaodi Oranusi ${ }^{1 *}$ Omotayo Adegbuiyi ${ }^{2}$, Ebeguki Igbinoba ${ }^{3}$ and Oluwakemi Oreagba ${ }^{4}$}

\author{
Ms. Covenant University, Nigeria, oranusi.chikaodi@stu.cu.edu.ng \\ Ass, Prof. Dr., Covenant University, Nigeria, omotayo.adegbuyi@covenantuniversity.edu.ng \\ Dr. Covenant University, Nigeria, egbeguki.igbinoba@covenantuniversity.edu.ng \\ Ms. Covenant University, Nigeria, oluwakemi.oreagba@stu.cu.edu.ng \\ "Corresponding Author
}

\begin{abstract}
The media role is to protect and educate the general public with accurate information against misleading practices experienced from the manufacturers and marketers of consumer products operating in the market economy. However, consumer education role of the media remains a major task in the developing countries such as Nigeria. This paper therefore, evaluates on education role by the media on consumer protection in the Nigerian pharmaceutical industries. This study adopted a conceptual review of extant literatures. Based on the conceptual, empirical and theoretical review, findings revealed a careless attitude of the consumers towards their sovereign rights and attributed it to poor education, ignorant, poor perception, skepticisms, limited and irregular provisions of information and lukewarm interest attitudes that exist among consumers and the media. Hence, the study affirms that the government should collaborate with media co-operations to embark on intensive sensitization and education of consumers on their rights, and how to enforce that right by making them know what they are losing for not protecting their rights. Second, the government of Nigeria should see it important to incorporate consumer education as a subject into the educational curriculum both at the primary, secondary and tertiary level of educations in Nigeria
\end{abstract}

Keyword: Consumer protection, Consumer education and Media Role

\section{INTRODUCTION}

Globally, the issue of consumer protection is a recognized concept that should deal with the realities and perceived differences in power relationship between the producers and consumers of goods and services. However, this relationship in power is noted by few scholars, Bello, Suleiman and Danjuma. (2012), Ndubisi, Anyanwu and Nwankwu (2016) as imbalance and inconsequential with the emphasis on consumer sovereignty to be laid in marketing definitions as the basis of marketing theory that should be built on the concept of consumer education, consumer focus and consumer driven offerings (Symczek, 2019). This imbalance relationship were seen by few scholars of extant literatures Moguluwa, Nwankwo, Anyasor, and Agina, (2018).as 
a philosophy of 'caveat emptor' (let the buyer beware) that were domicile in the ever growing and changing market environment where the producers and suppliers of goods and services are placed at an advantage and liberty over the consumers.

More so, because of this knowledge imbalance that had taken over the market place, consumers as a result, tend to suffer much in the hands of the marketers over trade transactions. The sovereign rights of the consumers as kings, queens, prince and princesses in the market economy were unfairly treated with violation, leaving the consumer hopeless and helpless (Ayozie, 2013). The balance of power were seen by many consumers as being held by the marketers due to lack of adequate information and protection from the government and nongovernmental bodies against the poor marketing practices experienced from the producers, suppliers and marketers at large (Ndubisi, et al, 2016; Moguluwa et al, 2018) Consumers ignorant of the content and characteristics of the products they buy have increased the risk of injury on society by way of sickness and disease on the health of the citizens. It has also contributed to consumer unconsciousness of their legitimate rights on choice, information, safety (UNCTAD, 2016). The manufacturers that supposed to promote the image of their product through promotion to maintain positive consumer loyalty and satisfaction have resorted to manipulative advertising from the media houses. The media manipulate the interest of the consumers through incomplete and distorted information's in disregard of the benefit and detriment effect on the consumers (Symczek, 2019). The complaints and responses of the consumers over their experiences against the marketing ethics of firms have seemed not to be profitable and favorable and in turn have resulted to consumer dissatisfaction on the products and services they buy (Abasilim, 2016; Ebitu, 2014).

Hence, the role of the media to inform and educate the public (consumers) on the safety of products in the market place has not yielded much substantial result (Symczek, 2019). It is against this backdrop that consumer protection becomes a primary focus of many developing nations especially Nigeria, to protect consumer rights and interest in the market environment owing to the imbalance ideology and consumer ignorant of their sovereign rights over the products and services they consume (Ndubisi, Anyanwu and Nwankwu, 2016; ljewere, 2011; Lal 2016; Tigerstrom, 2016). Subsequently, the development and methods of consumer protection differs in policy and institutional framework among nations based on the level of awareness and degree of discontent witnessed in each country.

\section{CONCEPTUAL REVIEW}

\subsection{Concept of Consumer Protection}

There have been several debates on the proper definition of the 'customer' who needs to be protected; nevertheless, according to Abasilum (2016), a modern definition of the consumer is "the final user of a product or service given in the market for maximum benefit and satisfaction." According to the definition above, a consumer is not necessarily the person who buys the product, but rather the one who consumes up the commodity's worth, hence exhausting its exchangeable value. Consumers are defined by UNCTAD (2016) as "us all, and also the largest economic group in the economy, affected by almost every public and private economic decision" (Ebitu, 2014). They are also defined as "that person who buys a product for the purpose of consumption because he believes that the product's value can satisfy the needs or felt deprivation for which it is bought."

The idea of consumer protection was developed by UNCTAD to safeguard consumers from unethical actions by producers and service providers of goods and services in the market environment in both developed and developing nations such as Nigeria. It refers to the government's attempt to create a regulatory framework to safeguard and enforce consumers' rights over the goods and services they purchase. As a result, consumer protection serves two purposes: It safeguards the interests, rights, and safety of end users of products and services, and it stems from and is related to contractual agreements, according to UNCTAD (2016). Hence, consumer protection can be seen of as a way of regulating private law relationships. The nature and shortcomings of products and services, as well as the necessity for public regulation of private transactions, are in the public interest (Bello, Suleiman, and Danjuma, 2012; Ayozie, 2013; Worlu, Adegbuiyi, \& Kehinde, 2016).

Based on the focus of this study, the researcher limits its assessment on consumer education and government agencies responsible for the protection of consumers' rights in the market environment. Thus, the following agencies were established by the Nigerian government to control information and educate the public on their rights against negative experiences from the producers, marketers and distributors of goods and services. 


\subsubsection{Consumer Protection Agencies}

\section{A. Consumer Protection Association of Nigeria (CPA)}

The Consumer Protection Association of Nigeria (CPAN) was founded in September 1980 with the following goals:

a. To encourage and stimulate consumers' interests and understanding of the products and services they purchase.

b. Ensure that consumer goods and services are merchantable and of acceptable quality.

c. To improve the atmosphere for interaction among customers, government officials, producers, and middlemen.

d. To work with the government and other entities in order to best represent the needs of customers.

e. Assisting consumers in finding redress for conflicts over products and services purchased by acting as a clearinghouse for customer grievances (Ayozie, 2013).

\section{B. Consumer Protection Council (CPC)}

According to Dibie et al. (2018) Ndubisi et al. (2016), Udoma and Osagie, (2019), Piwuna, (2016), Consumer Protection Council, was created by Act No. 66 of 1992, as a Federal Government parasternal with the following responsibilities:

a. The right to be safe and free from unsafe goods and services for customers.

b. Consumers have the right to be educated so that they are aware of and protected from fraudulent, deceptive, or misleading practices, as well as to have access to reliable information and data that allows them to make informed choices and judgments.

c. The right to assist consumers in selecting and obtaining a variety of goods and services at reasonable and competitive rates.

d. The ability to communicate and represent consumer preferences in economic and political decisions, as well as the right to assist customers in being heard.

e. The right to educate consumers in order for them to become competent and educated consumers who can function effectively in the marketplace.

f. Under the CPA Act of 1992, the right to redress and compensation for misrepresentation of poor products or services. To improve operating performance and enable easier access to clients, the Act established a federal council and a state committee in each of the country's states.

\section{The Advertising Practitioners Council of Nigeria (APCON)}

The Advertising Practitioners Council of Nigeria was established by the Advertising Practitioners Registration Act No. 55 of 1988 (APCON). According to Ebitu (2014), the Act granted advertising in Nigeria merited state legal recognition as a specialty and allowed APCON to control and supervise the practice of advertising in Nigeria in all dimensions, as well as to defend consumers' rights in Nigeria in the following areas:

a. To ensure that consumers are not offered fraudulent products.

b. To protect consumers from deceptive and misleading advertisements.

c. To protect customers from poisonous products and contaminated goods.

d. To ensure that goods are produced according to approved requirements, preventing customers from being sold defective and adulterated products and drugs;

e. To prevent defrauding customers by credit sales.

\section{Nigerian Broadcasting Commission (NBC)}

The Nigerian Broadcasting Commission was established in 2004 under the NBC Act of 2004. By the virtue of its regulatory role, Nigerian Broadcasting Commission is assigned with the duty of receiving, considering, 
educating, informing and instigation of consumers' complaints through broadcasting services.

\subsubsection{Consumer Education}

Consumer education, according to Moguluwa (2018), is the degree to which the consumer is aware of its rights as a consumer. The amount level of information made available to the consumer through consumer education is known as consumer awareness. Several scholarly studies have proved the link between consumer education and consumer awareness is a significant factor that keeps an economy moving as it holds the companies of nations accountable for what they sell and how they sell their products and also gives consumers control over their purchases. It also helps the consumers of any nation to exercise their right well and to make the best use of resources within their reach such as time, money, knowledge and ability (UNCTAD, 2016). Vijayakumar \& Venugopal (2012) opine that consumer education is the key to consumer rights awareness. UNCTAD, 2015 indicated that an essential role of consumer protection agencies is to assist the consumer in knowing their rights with regards to product safety. These rights should be narrated in an easy language void of ambiguous words to enable the consumer to understand the information.

In terms of defending consumer rights, several previous scientific publications have demonstrated a strong correlation between consumer information and successful consumer education (Nair, 2012). According to Bello, Aduke, and Danjuma (2012), when customers' knowledge is low, consumerism is absent. Thus, there exists a relationship between consumer education and consumer information. According to Ayozie, (2013); Oko and Osuagwu, (2013), consumer education in Nigeria is currently operating at a low level, and this was attributed to the weak commitment of the government to consumer education and low consumer awareness in the market place. Though the government has enacted the Consumer Protection Act 2004 to oversee consumer challenges, it has not enhanced consumer protection due to low consumer education. In developed countries, for instance, educational institutions play a significant role in raising consumer right awareness. Consumer rights affairs were embedded in the syllabus of educational institutions; this helps to create a more comprehensive and spread of information of consumers' right among consumers. (Moguluwa et al., 2018; Vijayakuma and Venugopal, 2012).

In Nigeria, on the other hand, consumer rights education is not included in the educational institution's curriculum. At the same time, statutory agencies and bodies such as the Consumer Protection Council, Consumer Awareness Group, and the Standard Organization of Nigeria, among others, were found to have performed below expectations in the Moguluwa, et al, (2018) study, aside from the credited landmark created by NAFDAC under the leadership of Late Prof. Dora Akunyili, (2000-2010) that raised consumer awareness.

Nwaizugbo and Ogbunankwor, (2013) assert that in Nigeria, even where the consumers are aware of their rights, they do not have the information on which agency to approach and how in the event of abuse. Hence, the specific knowledge and information on consumer rights and protection are seriously abated due to communication mode and intensity as factors that could affect consumer information dissemination. According to Jayasubramanian and Vaideke (2012), a lack of appropriate communication affects public awareness of consumer rights and protection measures. For communication to be effective, the channel of communication must be right, and the intensity sustained. According to Moguluwa et al. (2018), the factors that led to the success story of NAFDAC include among other things, the sustenance of high intensity of information dissemination using different channels of communication to ensure that every consumer was reached. The preliminary finding of this study revealed that most consumers are generally aware of the existence of consumer rights, yet lacked the specific knowledge of what these rights are or the agencies to approach in case of a breach.

However, information, as it is wisely said, is "knowledge and knowledge is power and ignorant is not an excuse from abuse" corresponds to the biblical injunction that states "My people perish for lack of knowledge" As a result, Oyedepo (2019) defined information as "any bit of news that influences individual thought and action" and "it is the force that dominates the world." Thus, being informed entails not only knowing something, but also knowing how to use it. His study further emphasizes that information is a product of intelligent search that is only available to explorers as it doesn't just jump on people. Hence, this assertion strengthens the opinion of Fasakin, Oyero, Okorie and Amodu, (2017) that sees information as power of nations that are determined and controlled by the nature of affairs in those nations.

\subsubsection{Media Role on Consumer Education}

Globally the education roles of the media in the advancement of information to the people and society at large

ISBN: 978-605-06286-5-4 
have enormously been appreciated in all countries of the world. Generally, civilization is characterized by the impact of media on its structure and value system. The problems of the society, social groups and individuals are advertised by the media. The media do many social-economic problems, education of the consumers and social awakening. Presently, the role of media has broadened as it deals with problems of current importance and has added many other activities such as entertainment, education and enhancement of social structure, hence, media were seen as an electronic mirror of modern society that emphasises on needs, aspiration, expectation and failures of nations (Nabirasool \& Prabhkar, 2014).

In the current past, media were seen as having undertaken the job of consumer education by fighting against the exploitation of consumers in the market place in other to sustain consumer education. Still, presently the activities of media as earlier mentioned in this study were seen to be influenced by many manufacturers, marketers and distributors who resorted to manipulative advertisement through media houses and other media outlet charnels of information (Symczek. 2019). Besides, Kareem, Rashidi, Abulla and Mahmood, (2016) have indicated in their study that the impact of media may be seen as having a good influence on the development of behavioural patterns, cultural and social impact on the individual and society with more emphasis that media may have less impact on the society due to change in behavioural patterns of life towards other vital issues such as political economic and social issues. Subsequently, the role of the media to consumer education has been recognized and summarized in two ways by Kareem et al. (2016), and they include mass media and social media.

i. Print media publications (newspapers and magazines), broadcasting news (television and radio), and the newest digital versions of media outlets such as digital newspapers, blogs, and others focus on the distribution of information to the general public or targeted groups of the public.

ii. Social Media: This term refers to a wide range of digital platforms used by the media, including social networking sites such as Facebook, Twitter, and Instagram. Pinterest, YouTube, Linkedln, and other sites are examples.

Traditional media, on general, has a larger audience than social media, allowing for more targeted information distribution. As a result, social media provides more information control than traditional media.

\section{THEORETICAL FRAMEWORK}

The purpose of this study is to look into the media's role in consumer protection and consumer education in the Nigerian pharmaceutical business. As a result, the theoretical foundation for this research is developed from stigler's Economic Theory of Regulation (1971).

\subsection{Economic Theory of Regulation (Stigler, 1971)}

Stigler's theory of economic regulation was modified from capture theory principles into a transformed theory of economic regulation based on public interest theory and private interest theory. Regulation, according to economic theory, is an economic aim whose distribution is safeguarded by the laws of demand and supply. On the demand side, the economic regulation hypothesis contends that industrial organizations tend to have more market information than other stakeholders such as consumers, and that as a result, a cooperative interest group (government) interfered to defend the market place. On the supply side, the theory claims that policymakers' regulation will be more effective than the opposition group as long as demand comes from policymakers. Economic theory, according to Stigler, exists to improve the wealth and influence of its members through regulation. Hence the theory addresses the objective of this study through the regulatory role of the government on consumer education. In addition, supplement to this theory id cultivation theory.

\subsubsection{Cultivation Theory (George Gerbner, 1967)}

George Gerbner proposed the idea in 1967, based on the assumption that mass media have quiet effects on consumers who unknowingly acquire the dominating symbols, pictures, and messages of the media, which the theorist referred to as "cultivation of dominant image pattern." According to the notion, long-term exposure to television and other media outlets can cultivate widespread belief around the world.

\section{REVIEW OF EMPIRICAL STUDIES}

Lack of consumer awareness: A major challenge for electricity consumer protection in Nigeria was the subject of 
a study conducted by Usman, Yaacob, and Rahman (2015) with the goal of examining the issues confronting consumer protection in Nigeria, with a focus on the Consumer Protection Council (CPC) Act 2004. The study's goal was to look into the difficulties of consumer protection in a deregulated electricity market. The study used a qualitative approach, conducting twenty in-depth semi-structured interviews with relevant stakeholders involved in consumer protection and standard setting in the Nigerian electricity sector. The study also used the Benner's interpretation phenomenon, thematically examining the participants' everyday practical experience and perceptions on the challenges of consumer protection and standard setting in the Nigerian electricity sector. The study's findings found that customers in the Nigerian electrical industry face a number of consumer protection concerns, the most significant of which is a lack of consumer sensitization and information awareness as a result of their ignorance. As a result, the report proposes consumer education and illumination on how to approach relevant agencies with complaints about any rights violations.

A study on social media and consumer knowledge of manufactured food was conducted by Kareem, Rashidi, Abulla, and Mahmood (2016). The study's goal was to look into the importance of social concerns and the function of social media in raising consumer awareness about manufactured foods. The study used a qualitative approach by using a tried-and-true questionnaire survey method. Respondents were chosen using a stratified sampling technique based on the organization's full-time employees. According to the study's findings, social media played a larger effect in consumer knowledge of manufactured food goods than traditional social media.

Mazlan, Radzuan, and Barker (2014) conducted a study on consumer education in the creation of a consumerconscious nation with the goal of determining if consumer education in Malaysia has met its goal of raising public awareness. In order to attain the study's goal, the researchers used a qualitative approach that included a faceto-face personal interview with a group of stakeholders. Secondary information on consumer issues was gathered through an online service, newspapers, journals, and textbooks. Consumers are exposed to risks and dangers as a result of using subpar products/services due to a lack of formal and informal knowledge, according to the findings. The findings, however, were consistent with the study of (Zhang, Chen, Lytras \& Sun, 2014) on the role of social media in collaborative learning.

\section{METHODOLOGY}

This paper adopted a conceptual review of extant literatures, academic journals and online materials were the main source of information utilized on this study. The aim of this review is to gather and summarize all empirical evidence from the literature that pertains to the study's subject. By searching the reference lists of pertinent articles, additional papers were discovered.

\section{DISCUSSION OF FINDINGS}

The use of social media has become ingrained in the internet world, yet not many consumers are aware to take the educational advantage (Sharkh, Jamro, Mahar, Magsi \& Bhatti, 2016).. This paper contained an elaborate discussion on the education role by the media as well as the necessary measures that guide consumer protection agencies to protect consumer interest against misleading information in the market economy. The study also looked into the media's role in consumer protection education in the Nigerian pharmaceutical business. However, from the result of many extant literatures, the level of knowledge awareness witnessed among consumers of goods and services were at a low state due to consumer ignorant, low literacy level, poor perception, limited and irregular provision of information, scepticisms and lukewarm interest attitude that exists among the consumers and the media (Abasilim, 2016; Moguluwa, et al, 2018)

Subsequently, few scholars have revealed that the level of knowledge awareness and consumer education have been acknowledged with little input on the public sector due to lukewarm interest attitude of the media on the issues of consumer concern (Ayozie, 2013; Sharkh, et al.,2016). Other scholars found out that many consumers adopted a positive attitude toward government ideas in building more awareness on consumer rights (Mazlan, Redzuan \& Bakar, 2014)

\section{CONCLUSION}

Social media such as electronic media is a mirror of the millennium and of the times that connects the mass public to the realities of life situations around them. Hence, media is an integral part of our life with tremendous impact on our present and future society. Media influences consumers of all age and play a major role in building good relationship between the producers, marketers and consumers of products/services. The 
promotion of fair marketing practices and good code of conduct in the market environment for all consumers and businessmen are the task that only the government and the media can shoulder.

However, the concept of ethic that centres on ethical requirement on morality in the professional and organisational institutions could only be fostered by the media. Unfortunately, the media role in protecting and educating the mass public have been socially abused by potential producers and marketers of consumer goods lobbying after cooperate image and profit maximization.

\section{RECOMMENDATIONS}

i. The study recommends a good collaboration among the government and media organisational bodies in Nigeria and other countries to have a common goal with initiative measures on enhancing the effective enforcement of quality consumer education in Nigeria.

ii. The Advertising Practitioners Council of Nigeria should make it a priority to monitor and regulate media practices in Nigeria in order to provide the general people with high-quality information education.

iii. The Nigerian Consumer Protection Agency should see it as a task to collaborate with other agencies, particularly the Nigerian Broadcasting Cooperation and other media outlets, to embark on intensive sensitization and education of consumers on their rights, as well as how to enforce those rights by making them aware of what they stand to lose if they fail to protect those rights.

iv. The government of Nigeria should see it important to incorporate consumer education as a subject into the educational curriculum both at the primary, secondary and tertiary level of educations in Nigeria

\section{Further Scope}

This study is limited to consumer protection and consumer education role of the media in the Nigerian pharmaceutical sector. However, there is need for wider scope to further research on this study by other scholars that will be interested in the research.

\section{ACKNOWLEDGEMENTS}

Covenant University (Center for Research, Innovation and Discovery)) is deeply appreciated for their sponsorship and financial support in this study.

\section{REFERENCE LIST}

Ayozie, D.O. (2013), Consumerism the shame of marketing in Nigeria challenges to corporate practices. IPBJ 5 (1), 1-30.

Bello, B., Suleiman, A. \& Danjuma, I. (2012). Perspectives on consumerism and consumer protection act in Nigeria. European Journal of Business and Management. 4(10), ISSN: 2222 - 2839. .

Dibie, V. M., Unanam E. I., Uwasomba C. E. \& Onyemali M. O. (2018). Place of Consumerism in Nigeria International Journal of Marketing and Communication Studies. 3(1), 14 - 20.

Ebitu, E. T. (2016). Marketing strategies and the performance of small and medium enterprises in Akwa-lbom State, Nigeria. British Journal of Marketing Studies. 4(5), .51-62

Fasakin, A., Oyero, O., Okorie, N. \& Amodu, L. (2017). The media as both friend and enemy of the state, International E- Journal of Advances in Social Sciences, 111(9), 954-959

ljewere A. A., (2011). Consumerism in Nigeria, JORIND, 7(12), 186-192

Jayasubramanian, P. \& Vaideke, A. (2012). A study on consumer awareness and attitude towards consumer protection measures. Indian Journal of Applied Research. 1(12).

Kareem, J., Rashid W., Abdulla, D. \& Mamood, O. (2016). Social media and consumer awareness towards manufactured food Cogent Business and management (3) 1-5 
Lal, S.B. (2016). Introduction to consumer rights and responsibilities, Public Health environment and Social Issues in India, 279-329

Mazlan, D., Redzuan, A. \& Bakar, D., (2014). Consumer education in creating a consumer conscious nation, Social and Behavioural Sciences, 155(2014) 448-453

Moguluwa, S. C, Nwankwo, N. L, Anyasor, O.M \& Agina, E. K (2018), Consumerism, business practices and government regulations: A study of consumers in Enugu state, Nigeria. International Journal of Multidisciplinary Research and Development. 5 (2), 75-86.

Nabirasool, D. \& Prabhakar, F. (2014). Role of media in consumer protection. Journal of Business and Management 2(1), 1-5.

Nair, I. (2012). Assessment of consumer awareness amongst undergraduate students of Thane District - A case study. International Journal of Scientific and Research Publications. 2(5).1-8

Ndubisi, E. C., Anyanwu, A. V. \& Nwankwo, C. A. (2016). Protecting the Nigerian Consumer: An Expository Examination of the Role of Consumer Protection Council. Arabian Journal of Business and Management Review. 6 (4), 2 - 7.

Nwaizuruigbo, C., \& Ogbunankwo, C., (2013). Measuring consumer satisfaction with consumer protection agencies: Insights from complaints to CPA offices in Anambah state. International Journal of small Business and Entrepreneurship Research 1(2) 12-28

Oko, A, \& Osuagwu L. (2013), Consumerism the Nigerian experience: Study of the food and drink industries 1980-2012. Business and Management Horizons, 1 (2), 18-46.

Oyedepo, O. D. (2019) Ruling your world: A recipe for impactful living. Dominion Publishing House. ISBN: 978978-290533-8

Piwuna, M. (2016). Emanation of consumer protection under the Nigerian communication commission act, 2003. Journal of Education \& Social Policy. 3 (4), 101-110

Shaikh, H., Jamro, W., Mahar, J., Magsi, A. \& Bhatti, A. (2016). Does social media impacts learning? An empirical study, In proceedings of The $1^{\text {st }}$ International Conference on Innovation in Computer Science \& Software Engineering (ICONICS, 2016), Ned University, Karachi

Smyczek, S. (2019). Consumer protection standards in Europe, Wydawnictwo Placet Retrieved: https://depot.ceon.pVhandle/123456789/16995

Stingler J., (1971). The theory of economic regulation, The Bell Journal of Economics and Management Science, 2(1), 3 - 21

Tigerstrom, (2016). A consumer protection perspective on regulation for healthier eating, Dalhousie Law Journal, 39 (2)

Udoma U. \& Osagie, B., (2019).When product go wrong: A synopsis of product recall requirements in Nigeria. Insomnia 1 (1)

United Nations guidelines for consumer protection, (2016): UNCTAD. Retrieved: https://unctad.org/en/PublicationsLibrary/ditccplpmisc2016d1 en.pdf

Usman D., Yaacob N., \& Rahman A, (2015). Lack of consume awareness: A major challenge for electricity consumer protection in Nigeria. Canadian Center of Science and Education 11(24), 240-251

Vijayakumar, P. \& Venugopal, P. (2012).Consumer awareness and the role of educational institutions, A Journal of Radio International Educational and Research Consortium RIJS, 1(5) ISSN: 2250-3994

Worlu, R., Adegbuyi O. \& Kehinde J, (2016). Marketing principles and applications, (2 ${ }^{\text {nd }}$ Ed.) Macrowly Publishers, ISBN: 978 - 978 - 082-134 - 4.

Zhang, X., Chen, H., Pablos, P., Lytras, D., \& Sun Y. (2016). Coordinated implicity? An empirical study on the role of social media in collaborative learning, International Review of Research in Open and Distributed Learning, 17(6), 122-144 